\title{
Need Analysis for the Development of STEM-PjBL Physics Teaching Materials to Improve Students' Problem Solving Ability in the 21st Century
}

\author{
Lis Tyas ${ }^{1}$, Harjana $^{2}$, Daru Wahyuningsih ${ }^{3}$ \\ ${ }^{1,3}$ Teacher Training and Education Faculty, Sebelas Maret University, Surakarta, Indonesia \\ ${ }^{2}$ Mathematics and Natural Science Faculty, Sebelas Maret University, Surakarta, Indonesia
}

Received: 28 Nov 2020; Received in revised form: 23 Jan 2021; Accepted: 13 Feb 2021; Available online: 27 Feb 2021 C2021 The Author(s). Published by Infogain Publication. This is an open access article under the CC BY license (https://creativecommons.org/licenses/by/4.0/).

\begin{abstract}
This study aims to analyze the needs of teachers and students related to the development of physics teaching materials in the 21st century towards increasing of ability of the grade X High School students in solving problems. The research sample in this study were the students of grade $X$ in the city of Surakarta. Data analysis was carried out descriptively, the data obtained in this study were data from interviews, questionnaires and student preliminary tests. The results of this study indicate that students need supporting teaching materials in the form of learning media accompanied by pictures and videos equipped with a learning model that can improve students' ability to solve problems, namely STEM-PjBLbased E-module.
\end{abstract}

Keywords-Teaching materials, E-Modules, STEM-PjBL, Problem solving

\section{INTRODUCTION}

The transformation process of the 21 st century as the Era of Human Capital which is a period in which science and technology, especially communication technology, are developing very rapidly leading to an intense free competition in all aspects of human life [1], describes these changes as follows[2]:

In an economy driven by innovation and knowledge, in marketplaces engaged in intense competition and constant renewal, in a world of tremendous opportunities and risks, in a society facing complex business, political, scientific, technological, health and environmental challenges, and in diverse workplaces and communities that hinge on collaborative relationships and social networking - the ingenuity, agility and skills of the people are crucial to competitiveness

The collaboration of science and technology is one way to adapt in facing the development o the $21 \mathrm{st}$ century. This collaboration can be implemented in the field of education. Science which often conveyed in conventional form must be changed by following technological developments, so that the quality of human resources can develop with the interconnectedness of science and technology. This aims to prepare the generation to be ready to compete in the life of the $21 \mathrm{st}$ century and in the future. The changes that are intended are changes that develop without discarding or abandoning the old ways. The current educational challenge is to be able to produce Human Resources (HR) who have strong communication and collaboration skills, experts in using technology, creative and innovative thinking skills and the ability to solve problems [3].

Kemdikbud formulates that the $21 \mathrm{st}$ century learning paradigm emphasizes the ability of students to find out from various sources, formulate problems, think analytically and collaborate and collaborate in solving problems ([4]. Figure 1 is the framework of the $21 \mathrm{st}$ century learning: 


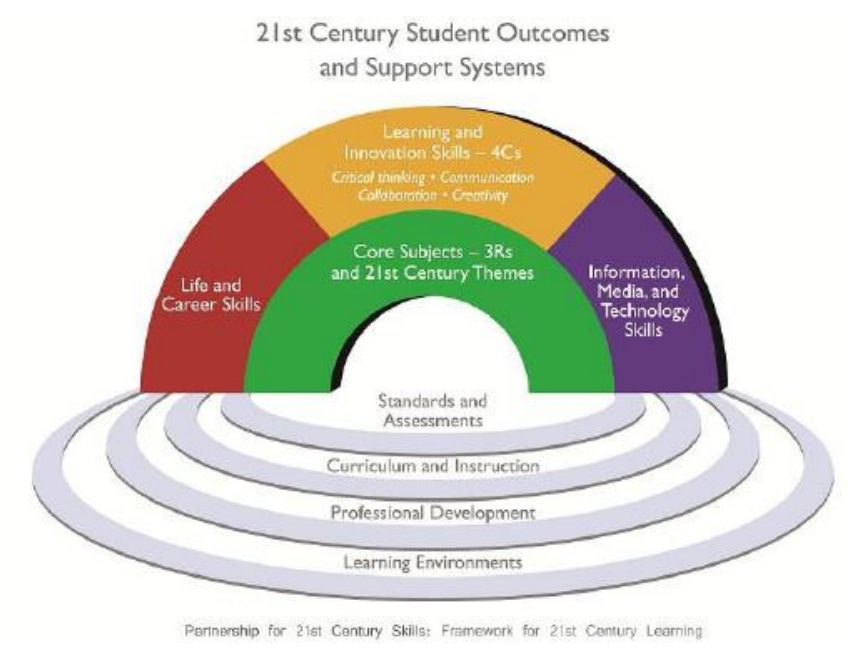

Fig.1: Framework of the 21st Century Learning (Litbang Kemdikbud 2013)

The framework of the 21st century learning according to the National Education Standards Agency are: (a) Critical-Thinking and Problem-Solving Skills, able to think critically, laterally, and systemically, especially in the context of problem solving; (b) Communication and Collaboration Skills, able to communicate and collaborate effectively with various parties; (c) Creativity and Innovation Skills, able to develop their creativity to produce various innovative breakthroughs; (d) Information and Communications Technology Literacy, able to utilize information and communication technology to improve performance and daily activities; (e) Contextual Learning Skills, being able to have contextual independent learning activities as part of personal development, and (f) Information and media literacy skills, being able to understand and use various communication media to convey various ideas and carry out collaborative activities as well as interactions with various parties [5].

According to Husamah and Setyaningrum, the 21 st century learning is directed at a learning model that encourages students to find out from various sources of observation, not just being told. Learning is also directed so that students are accustomed to being able to formulate problems, not only to solve problems and train critical thinking instead of mechanistic thinking. Cooperation and collaboration are also emphasized in solving problems in the learning process [6].

One of the efforts taken by the government to improve the quality of education is the development of teaching materials [7]. Teaching materials need to be developed because they are one of the supporting facilities for delivering material in the learning process. Teaching materials that support the implementation of the $21 \mathrm{st}$ century learning paradigm are connected with developments in the field of technology. Technologybased teaching materials can make students adapt to current developments in the IT field. Students who are accustomed to using IT-based teaching materials also indirectly develop their abilities in this field and can develop the their human resources quality.

The results of research by Taufik Solihudin stated that the development of Web-based E-Modules is able to increase the students' knowledge competencies[8]. The results of research by Fengky Adie Perdana, stated that student motivation using the electronic physics module based on student process skills is better than conventional learning[9]. The results of research by Komang Redy Winatha, concluded that digital simulation learning using project-based interactive e-module can improve student achievement[10]. The results of research by Syamsurizal, stated that e-modules have an attractive appearance, which are easy to understand and easy to use[11].

Based on the explanation above, the purpose of this study is to analyze the needs for Physics teaching materials for grade X Senior High School to improve the problem solving skills in the 21 st century.

\section{RESEARCH METHOD}

This research is a descriptive study on the analysis of the needs of Physics teaching materials to improve problem solving abilities in the 21 st century. The descriptive approach serves to describe or provide an overview of the object under study through data or samples that have been collected as they are [12]. In addition, the descriptive research framework aims to capture and present the facts, realities, symptoms, and events that are desired to be raised appropriately [13]. The population of this study were 268 students of grade $\mathrm{X}$ Senior High School in Surakarta in the academic year 2020/2021. The instruments in this study were questionnaire instruments, interview instruments, and preliminary tests of students' problem solving abilities. Methods of data collection using interviews, questionnaires, and document review related to Physics learning.

The research procedure carried out is illustrated in Figure 2 [14]: 


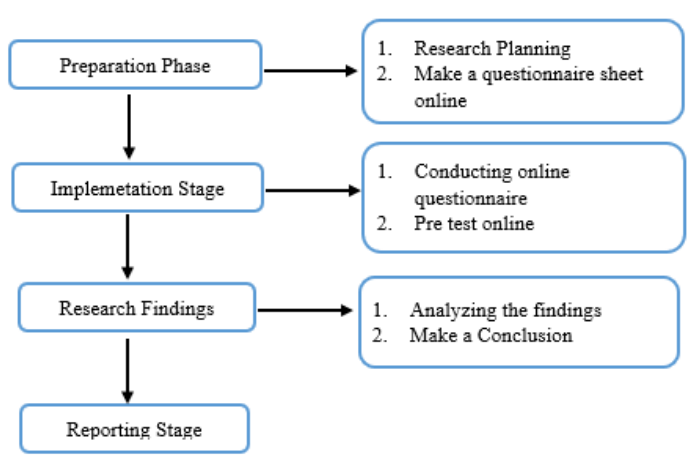

Fig.2: Research procedure(Widarti dkk, 2020)

\section{RESULT AND DISCUSSION}

The stage in conducting descriptive research is gathering information. The results of the research and information gathering stages are as follows.

Interviews with teachers and students aimed to determine the responses of teachers and students to the teaching materials and learning processes of physics in schools. The interview is one of the steps for taking data that can construct meaning in a particular topic [15], The results of the interview with the Physics subject teacher showed that the physics learning process was in accordance with the demands of the 2013 curriculum which used a direct and contextual approach. The contextual approach is an approach that involves applications in everyday life. In addition, teachers have also used several methods such as lectures, question and answer and discussion in the implementation of learning. The teaching materials used by the teacher are handbooks and worksheets that have been selected as needed. However, the use of modules and e-modules in learning is not optimal due to the lack of motivation within the MGMP scope to make modules and e-modules so that teachers do not make them. Therefore, the teacher agreed to the development of teaching materials by including a more varied teaching and learning process so as not to be monotonous. The results of interviews with students showed that students felt bored with Physics learning which contained material and question assignments. Moreover, students also need interesting and easy-to-use teaching materials in learning the concept of Physics. This strengthens that the development of Physics teaching materials is needed as a support for a fun Physics learning.

Analysis of student and teacher needs was carried out by giving questionnaire to obtain data about what teachers and students needed in Physics learning based on the process that had been carried out during learning. The results of the teacher needs questionnaire showed that the teacher used various approaches and varied learning models, but there is no teaching material in the form of e-modules that supports the teaching and learning process.

In addition to the responses from the teacher, Table 1 is the student response to the questionnaire given:

Table 1. Analysis of students' needs

\begin{tabular}{ll}
\hline \multicolumn{1}{c}{ Dimensions } & \multicolumn{1}{c}{ Students' responses } \\
\hline $\begin{array}{l}\text { The way students learn } \\
\text { Physics }\end{array}$ & $\begin{array}{l}\text { 82.5\% of students consider Physics a difficult subject. Problems experienced by students } \\
\text { are learning with material and question exercises monotonously, students experience a } \\
\text { burden in understanding physics because of the formulas that must be memorized so that } \\
\text { few students try to understand the concepts that exist in the material. }\end{array}$ \\
\hline $\begin{array}{l}\text { Students assessment of the } \\
\text { teaching and learning } \\
\text { process }\end{array}$ & $\begin{array}{l}49.2 \% \text { of students stated that the teacher's way of teaching physics was interesting. The } \\
\text { learning methods used were lectures, questions and answers, and discussions }\end{array}$ \\
\hline $\begin{array}{l}\text { Students assessment of } \\
\text { materials/textbooks }\end{array}$ & $81 \%$ of students have handbooks and 78\% of students find handbooks less interesting. \\
\hline $\begin{array}{l}\text { Students assessment of the } \\
\text { students worksheets }\end{array}$ & $\begin{array}{l}88.9 \% \text { of students have Student Worksheets which contain question sheets that must be } \\
\text { answered }\end{array}$ \\
\hline $\begin{array}{l}\text { Students' readiness to } \\
\text { receive research products }\end{array}$ & $\begin{array}{l}\text { 81\% of students stated that they have never used electronic modules and 73\% of students } \\
\text { have never used Science, Technology, Engineering and Mathematic Project based } \\
\text { Learning (STEM-PjBL) }\end{array}$ \\
\hline Other suggestions & $\begin{array}{l}\text { Engineering and Mathematic Project based Learning (STEM-PjBL) } \\
\text { Students expect a meaningful and fun physics learning with problem solving, imagination } \\
\text { and logic. The method used is discussion accompanied by instructional media in the form } \\
\text { of videos, games and practices. }\end{array}$ \\
\hline
\end{tabular}


Based on the responses from the respondents, students experienced boredom caused by monotonous learning

methods, namely learning materials and assignments. Assignments and homework are always exist and always related to the Physics formula. Students considered Physics lessons as a collection of formulas used to solve problems. Therefore, it is necessary to have a variety of learning methods so that the teaching and learning process is not boring and does not overwhelmed students. In addition, based on the analysis of the teaching materials used, $78 \%$ revealed that the teaching materials used were less attractive. Students provide suggestions for interesting teaching materials, which is a teaching materials that are accompanied by pictures, colors, and videos. Moreover, teaching materials can also be equipped with games and practices.

Physics learning can be a lesson that is able to provide understanding to students about the natural surroundings but is still carried out through an active and fun learning process. Physics learning is not just memorizing and remembering formulas without knowing the meaning of their use, but it takes conceptual understanding and understanding of a problem in physics. Students are expected to be able to relate a new information to concepts in accordance with what they already have. Therefore, the results of Physics learning are shown in the form of scientific products, scientific processes, and scientific attitudes.

STEM (Science, Technology, Engineering, and Mathematic) learning is a learning approach that connects four fields into one holistic unity. The purpose of STEM in the world of education is in line with the demands of 21 st century education, that students have scientific and technological literacy as seen from reading, writing, observing, and doing science, and being able to develop their competencies to be applied in dealing with problems in everyday life related to the STEM field of science [16].

STEM-based Physics learning can be done with the PjBL (Project Based Learning) learning model. The PjBL learning model emphasizes contextual learning through complex activities such as giving students freedom to explore, plan learning activities, carry out projects collaboratively, and ultimately produce a product result [17]. STEM-PjBL learning is project-based learning by integrating STEM fields. Physics requires mathematics as a tool in data processing, while technology and engineering are applications of physics. Some of the benefits of the STEM approach make students able to solve problems to be better, innovative, independent, logical thinking, and technological literacy [18].

Students' initial knowledge is given by giving 5 essay test questions. The first test was conducted to determine the students' ability to solve physics problems. There are four steps in the problem solving process that can be used as an aspect of measuring / analyzing problem solving according to Polya. Polya conveyed four steps of problem solving aspects, namely understanding the problem, compiling a plan, implementing the plan, and reviewing the results[19].

Table 2 is the results of the students' first tests.

Table 2. Results of the students' first tests

\begin{tabular}{lllc}
\hline No & Aspect & Indicator & Results \\
\hline 1 & Understand and problem & $\begin{array}{l}\text { Identification of the unknown aspects of the problem and } \\
\text { mentioning questions based on the problem. }\end{array}$ & $72,8 \%$
\end{tabular}

\begin{tabular}{lllc}
\hline 2 & Device a plan & Demonstrate Physics concepts that will be used to solve problems. & $65,35 \%$ \\
\hline 3 & Carry out the plan & Analyze the problem-solving process based on a plan. & $54,65 \%$ \\
\hline 4 & Look back over the result & Examining the accuracy of the answers to the questions. & $47,14 \%$ \\
\hline
\end{tabular}

The results of the students' first test showed that the aspect of understanding the problem was $72.8 \%$, which means that most students were able to identify what was meant by the problems presented. The aspect of making plans shows the results of $65.35 \%$ where students experience a low percentage of using physics concepts in solving problems. Aspects of implementing the plan get $54.65 \%$ results, students experience difficulties in the process of implementing the plans that have been written in the previous stage. Aspect of looking back over results gets $47.14 \%$, which state that students are less careful and rarely revisit the results that have been done so that errors are found in solving problems in the test. Based on the results of the first test of students 'problem solving abilities, it can be concluded that the students' ability to solve problems is still lacking to get the expected result. 


\section{RESULT AND SUGGESTION}

Based on the results of research conducted on grade $\mathrm{X}$ students in Surakarta, it was found that the teaching materials needed as supporting teaching materials in 21 st century learning are technology-based teaching materials, namely electronic modules or E-Modules. In addition, teaching materials that can improve students' problem-solving abilities are teaching materials with the STEM (Science, Technology, Engineering, and Mathematic) approach and can be done with the PjBL (Project Based Learning) learning model. Therefore it can be concluded that students need supporting teaching materials in the form of learning media that are in line with the challenges in the 21 st century equipped with a learning model that can improve students' ability to solve problems, namely STEM-PjBL-based E-module.

Suggestions that can be given for further research are the development of electronic-based teaching materials with the STEM approach and the Project Based Learning (PjBL) learning model to improve students' ability to solve problems.

\section{REFERENCES}

[1] Sidi. I. D, \& Setiadi. B. N. Manusia Indonesia abad 21 yang berkualitas tinggi di tinjau dari sudut psikologi 2013. [online]. http://himpsi.or.id/publikasi/. [Accessed: Dec 2, 2020]

[2] Partnership for 21st Century Skills. 21st century skills, education \& competitiveness. 2008. [online]. www.p21. org/storage. [Accessed: Dec 2, 2020].

[3] Miller, L. C., \& Northern, T. 21st Century skills: prepare student for the future. Kappa elta Pi Record.121123. 2011.

[4] Litbang Kemdikbud. Kurikulum 2013: Pergeseran Paradigma Belajar Abad-21. [online]. http://litbang. kemdikbud.go.id/index.php/index-berita-kurikulum/243kurikulum-2013-pergeseran-paradigma-belajar-abad-21 [Accessed: Dec 2, 2020].

[5] BSNP. Paradigma Pendidikan Nasional Abad XXI. Badan Standar Nasional Pendidikan. 2010.

[6] Husamah dan Setyaningrum,Yanur . Desain Pembelajaran Berbasis Pencapaian Kompetensi.Jakarta: Prestasi Pustakakarya. 2013.

[7] Bappenas. Rencana Kerja Pemerintah 2009. Jakarta: Kementerian Perencanaan Pembangunan Nasional. 2009.

[8] Solihudin, T. Pengembangan E-Modul Berbasis Web Untuk Meningkatkan Pencapaian Kompetensi Pengetahuan Fisika Pada Materi Listrik Statis Dan Dinamis SMA. Jurnal Wahana Pendidikan Fisika. Vol.3 No.2 : 51-61. 2018.

[9] Adie Perdana, Fengki. Development of e-module combining science process skills and dynamics motion material to increasing critical thinking skills and improve student learning motivation senior high school Int. J. Sci. Appl. Sci.: Conf. Ser. Vol. 1 No. 1 (2017) 45-54. 2017.
[10] Edhi Winatha, Komang. The Usage Effectivity Of ProjectBased Interactive E-Module In Improving Students' Achievement. Jurnal Pendidikan Teknologi dan Kejuruan, Vol. 24, No. 2, October 2018, 198-202. 2018.

[11] Syamsurizal. Pengembangan E-Modul Berbasis Keterampilan Proses Sains Pada Materi Kesetimbangan Kimia Untuk Tingkat SMA. Prosiding SEMIRATA 2015 bidang MIPA BKS-PTN Barat Universitas Tanjungpura, Pontianak Hal. 655 - 661. 2015.

[12] Sugiyono. Metode Penelitian Pendidikan Pendekatan Kuantitatif,Kualitatif, dan R\&D. Bandung: Alfabeta. 2013.

[13] Raco, J. R. Metode penelitian kualitatif. Gramedia Widiasarana Indonesia. 2010.

[14] Widarti, H.R., Rochim, D.A., \& Syafruddin, A.B.The Development of Electrolysis Cell Teaching Material based On STE-PJBL Approach Assisted By Learning Video: A Need Analysis. Jurnal Pendidikan IPA Indonesia (JPII) 9 (3) Halaman 309-318. 2020.

[15] Sugiyono. Metode Penelitian Kuantitatif, Kualitatif dan $R \& D$. Bandung:PT Alfabet. 2016.

[16] Bybee, R. W. The case for STEM education: Challenges and opportunity. Arlington, VI: National Science Teachers Association (NSTA) Press. 2013.

[17] Rais. PROJECT-BASED LEARNING : Inovasi Pembelajaran yang Berorientasi Soft skills. [online] (http://digilib.unm.ac.id/files/disk1

/1/universitas\%20negeri\%20 makassar-digilibunmdrmuhraiss-20-1-makalah-a.pdf.), [Accessed: Dec 10, 2020]. 2010.

[18] Stohlmann, M., Moore, T.J., \& Roehrig, G.H. Considerations for teaching integrated STEM education. Journal of Pre-College Engineering Education Research (JPEER), II(1): 28-34. 2012.

[19] Anglin, K. L. Math Word Problem.USA: Wiley Publishing. 2004. 